シンボジウム

\title{
道德教育における教育心理学的問題と
} 研究方法に関するシンポジウム*

\section{提案沢田慶 輔}

道徳教育が何であるべきかとい.5ことについては，い ろいろな意見があることと思つ。それをできるだけ限定 して話を進めないと, シンボジゥムす焦点が活やけてく るおそれがあるので，現実的にはわが国の道徳数育の今 後の動向を決定するのに最も広汎な影響を及ぼすである 万と予測される, 交部省発表の小中学校「道徳」実施要 網に示されている道徳教育の考えを中心にして問題をて ろいあげていくことにしたい。

1 目慓・内容の設定に関寸る問題

「道徳」実施要綱に示された「目僄」は教育課程審議会 の中学校分科会で採択された「道徳教育の基本的方針」 に基ついたものである。「道徳教育の基本的方針」は教 育基本法, 学校教育法の精神や目標を分析し, 整理・組 織し, 総合して, 人間尊重の精神とそれに基うくく共同体の 倫理を道德教育の指導原理として設定したものである。 この目標は日本国の歷史的課題として設定されたるので その設定には教育心理学は積極的役割を演じていない。 その目標を5けて指導内容（中学校「道徳」実施要綱で

※この巻から，毎号、シンポジゥムとレビュー とを交互にのせる予定です。シンポジゥムは， 当分の間, 現在問題になっている教育上の諧問 題をとりあげて，それについての教育心理学的 諸問題とその研究法を検討して行く計画で，そ の第 1 回として，道徳教育の問題をとりあげま した。次回には学習指導の問題が予定されてい ますが，取り上げることを希望される問題があ りましたら，編集部に御申越下さい。次号のレ ビューは腷波を予定しております。（編集部）

\begin{tabular}{|c|c|c|c|}
\hline 提 䅈 & 沢 & 慶 & 輔 \\
\hline 報 告 & 天野利武 & 牛島義友 & 長島貞夫 \\
\hline
\end{tabular}

は内容）か設定されているわけであるか，この指導内容 は目標を達成するなめに必要と考えられる下位目標であ り，子どもの行動の形で書きあらわされている。この下 位目標の設定は, 倫理学者, 教育学者, 心理学者, 現埸 の教師などの共同討議によつて行われたもので，直接に 科学的調査の成果に基ついて行われたものではない。小 学校の「指導内容」に関しては, 低学年, 中学年, 高学 年における重点のちがいが示されており，また中学校の 「内容」には下位目標との関連に抢いて, その目標の達 成を困難ならしめる中学生の現実のすがた（たとえば, 「生命を尊び安全の保持に努め, 心身ともに健全な成長 と発達をとげるように励もら」といら下位目標に関連し ては，その場の気分に負けやすいこと，節度をまもりに くいこと，均衡を失した生活をしやすいこと，など）が 示されているが, これらはこれまでの教育心理学的研究 の成果と現場教師の経験に基づいてて設定されたるのであ るといえることはいえるのであるが，中学校の内容に関 する筆者の経験に関する限りは, 真に科学的な研究の成 果を利用することに困難をお法えた現状であつて, 教育 心理学的研究成果が重要な役割を演じたということは遠 虑しなければならないだろう。このような下位目標の設 定には, 教育心理学的研究が多つと重要な役割を演じな ければならないと考光る者の一人であるので，それに関 してどのような研究が必要であるかを考えてみることに しょう。

下位目標は小学校の要綱では，(1)日常生活の基本的な 行動様式を理解し，これを身につけるように導く (2)道 徳的心情を高め, 正邪善悪を判断する能力を養うように 導く (3)個性の伸畏を助け, 創造的な生活態度を確立す るよ5に導く (4)民主的な国家・社会の成員として必要 な道徳的態度と実践意欲を高めるよ5に導く，とい34 つリカテゴリーにわけられ，中学校の要綱では，(1)道徳 性の基盤としての日常生活の基本的行動様式を身につ 
け，活用できるようになるために必要なるの，(2)個人個 人が，自律的に道徳的価值を追求し，それを対人関保の 中に生かし, 豊かな個性と創造的な生活態度を確立して いくために必要なるの, (3)家庭, 学校, 国家, 社会のよ うな集団の成員として必要な道徳性を高めていくために 必要なるの, の3つのカテゴリーにわけられているが学 校の道徳教育では, 道徳性のどの様相の指導に力点がお かるべであろらか。その力点のおき方は子どもの発達 段階によつて異るであろうからどの学年においてはどの 様相の指導が必要であろうか。またどのような種類の欲 望や対人関俰上の問題に関する指導がとくに必要なので

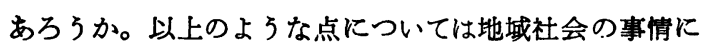
よる相違がかなり著しい場合があるである5が,ここで は日本国全体を通じて共通に設定される下位目標に限つ て考えてみることにしよ5。(それぞれの学校で具体的 な指導計画を立てる場合には地域社会の事情がじゅうぶ んに考虑されるへきことはいうまでるない。)

これまでの教育心理学者の道徳教育関係の研究は, 道 徳的な判断を下すことができる行為を出して，よい行為 と悪い行為という判定規準にしたがつて, 評定させるこ とにより, 子どすの道徳的判断が集団の棒準的な判断に とれだけ一致しているか逸脱しているか，あるいは子ど もの集団の平均的な道徳的判断の成長の寸がたがおと なの集団の標準的な判断にどれだけ近づいているか, 子 ぞもが所属している集団の一般的な判断のし方をその子 どあどう知覚しているか，それと子ども自身の判断の し方とにはどのようなズレがみられるか, というような 道徳的判断ないし道徳意識の問題に集中されていた観が ある。道徳教育において道徳的判断の様相が最も重要な 指導内容となることに異存はないが, 態度の様相もこれ に劣らず重要であると考えられるので, その発達につい ての研究が進まなければ, 設定される下位目標の重点を 明確にすることはできない。

下位目標設定に関しては，おとながそれぞれの目標の 必要性, 重要性をどのように評価するかの調査も行われ る。これはとくに教育心理学的研究というわけではない が，この意見調査が道德教育に関する高まいな識見をも つている人たちを対象として行われる場合には, 基本的 目標の設定に対して役立つものとなろう。地域社会の一 般人を対象として行われる意見調查では, その地域社会 の子どるたちの道徳教育においておとなが何を期待して いるかを明らかにすることには役立つが,それをそのま ま数育目標とすることができないことは明らかである。 それは基本的目標の達成に㟢与すると認められる限りに おいて，下位目標として採択されよう。子どもの道徳的
判断ないし道徳意識に関をる調査の結果も, それぞれの 内容の判断ないし意識に関して子どもの未熟な点を明ら かにし，かつそれぞれの学年における未熟な子どるの割 合が明らかにされる点で, その内容に関する指導はどの 学年が適当であるとい5ことについての示唆が提供され ることになるから, 下位目標の設定に役立つことであろ らか, 調査に用いられた項目の構造の検討は現在どのよ らに行われているのであろらか。項目は単に羅列的なの であろうか。そうとすれば，その調査結果を目標の設定 に利用する場合には, それぞれバラバラの特殊的な目䐼 を立てればよいと考えられているのであろうか。あるい は, 教育心理学的研究は, その結果がぞのよ $5 に$ 教育に 利用されるかについては一切考える必要はなく, 独自の 構想にしたがつて行われればよいのであろうか。筆者が この問題を提出するのは, 「道徳」実施要綱における指 導内容かいささか羅列的, 平面的であつて, とれがより 基碟的であり，どれがより系的なるのであるということ について明らかにすることができなかつたことに不満を 感じているからである。道徳判断に関してる, ある種の 内容に関して判断ができれば，他のある内容に関する判 断は容易であるという関係があるだろうと推定されるが これまでの調査の成果ではこの点はどのように考えられ ているのであろ5か。態度についていえば，人間として の誇をもち, 自分で考え, 決断し, その責任をとること に努めるとい5自尊と自律の態度と, 他人の人格を尊重 し，他人の立場に立つてものごとを考えてみようとする 態度とか，健全な人格形成, 人間関係発達の基礎である と考えられるので, その 2 つに焦点をしばつて, これら の態度の前提となるもの, これらの態度から派生するも の, これらの態度と相互に補強し合うもの, あるいは対 立拮抗するものが何であり, それらがどのよ5に発達し てくるものであるかを明らかにして, 態度に関する教育 目標を設定しなければならないと考える者である。この ような, 教育目標設定とい5目的のための教育心理学的 研究は, 調查の领域を限定することになるが, しかしど のような研究においてもその目的にしたがい多かれ少か れ研究の範囲は限定され, 事実の選択が行われているも のであるから, 調査の領域が限定されることは問題とな ることではあるまい。明確な問題意識をるつて調査の計 画を立て，その調查の成果に基づく教有の実践が有効な 成果をあげたかど5かを確実に反省して, 調査の計画が 基ついている仮説を絶えず検恠し，修让していくことを おこたらなければ，教育心理学的㼋究こしては適格であ ると考えられる。

これまで行われた道德的判断ないしは道德け諳に関す 
る調査は，教育とどのような関連をるつものとして計画 されたものであろらか。このことに答えていただくこと によつて, 教育心理学的研究がどのような問題意識をも つて,どのように行われるべきかいいて明確にしてい ただきたいと思う。

その結果がそれぞれの学校におけす指導計画の立案に 利用されることを予想する調查は，その地域社会の特殊 な必要をおとなや子どもを対象とする調査の中からひき 出してこなければならないという点においては, 国の共 通目標設定のための調査とはちがうが, 研究方法にはち がいは考えられないので, 特別には論じない。

2 判断と実践とのギャップについてて

道徳教育におい:て道徳的判断を適正に発達させること は前述したように極めて重要なことである。しかし道徳 的判断が正しくできれば，血い行為をしないということ は必ずしも保証されない。悪い行為をするのはどこか判 断に不じゆうぶんな点があるからだといら主知的な考え 方るあるか，心理学者はそのような考方方には替成でき ないのが一般であろう。動機つけをふくむ多かれ少かれ 持続的な行動の傾向としての態度か形成されているかど ろか, いいかえると自己の動機づけをどのように統御す るかの䫀向としての態度が形成されているかどらかが， 道徳的実践には重要な意味をるつている。したがつて道 徳教育のための態度調査は，何か望ましいかを钼念的に 判断して，あるいは調査項目作製者が望ましいと考えて いるもいを推察して，その線にそつて答えることになり やすい意見調査であつてはならない。順位をつけ，ある いは二者択一をする意見の間に価値の高下が予想される ものであれば，価値の高いるのを自分の意見として答え ることになりがちであるから，判断の調査と変りのない ものとなつてしまう。われわれに必要なのは子どすの近 い将来に批実践が予測できるような行動の傾向性と しての態度である。実践行動を動かす力としての態度で ある。そのような態度の発達を正確に測定することがで きなければ，目標の設定もできないし，指導計画子立た ないしどのような指導方法を用いることが適当である かを考えることもできない。自分をより望ましいと判断 される者にみせようという気持がはたらく余地がないよ ろに，価值の高下に関しては中性的な形で項目を書きあ らわして，それが事実として自分にあるかどうかを答え させる調査や，子どもたちの生活の中に participant observer として入りこんで，子どすたちの行動の傾向を 観察する方法や，プロジェクティヴ・テクニックがくふ 5されて道徳的態度が明らかにされ, 態度の弱い点があ ればこれを補強し，教育目標に反する態度があれば，こ
れを再構成する方法が構想されなければならない。態度 教育の方法につい・ては, カウンセリングや集団力学の研 究成果から多くの示唆を受けることができる。道德教育 に関して判断と実践のギャッブをうずめるための教育と しては, 学校教育の枠内におい、ては態度の形成がせい一 ぱいであり，すへてての問題について実践の指導まで行了 ことは不叮能であろうと考えられているが，るし態度の 形成が学校に打ける道徳教育において重要であるならば 態度形成の諸方法の効果を測定する研究を計画すること は意義あることであろつ。もちろん, 道徳的判断を指導 する方法にる改善の余地はあるわけ化から，指導の諸方 法の奻果を測定する研究を計画することもわれれれの今 後の課題であろう。

3 道徳性発達に扑ける学習の機制と条件について 道徳性の発達に関して, 子どもが現在どのような道徳 的行為をしているといろ現象が明らかにされるだけでは 教育には余り役立たない。その現象がどのような学習の 機制で発生しているものであるかが明らかにされなけれ ばならない。中学校「道徳」実施要糋で怯, 道德性の発 達の項で，賞罪，是認・否認による条件つうけ，親子の間 の愛情の交流，親に対する信頼感を前提とする親との同 一化による良心の形成, 他の尊敬・信賴の対象との同一 化, 人間として平等の立場で構成されている子どもたち たけの集団におい、て相互に統御し合うことによつて発達 する自律的道徳, 青年期においてて自主的判断の発達を了 ながす条件などが分析してあるが，これらはこれまでの 心理学的研究の成果に基づいたものだとはい方, 従来の 理論の多くは臨床的研究に基ついて提唱されたものであ

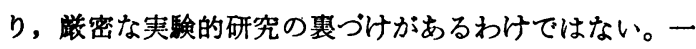
貫した理論的立場でじゆうぶんな検討を行つて，道德性 発達における学習の機制と要因とを一層明確にすること が, 奻果のあがる指導計画指導方法の考案に対して大 きな寄与をすることになるわけだから，このような研究 をどリように推進していくい゙きかについても御意見をう かがいたいと思う。現場ではこれまで生活指導の名の下 て，学級づくりを重視し，われわれ意識を高め,よい人 間関俰を確立することが最も基本的なことであると考え てきた。「道徳」実施要綱では，いろいろの集田，時に は利害の対立する集団との関係においてるよい人間関倸 を確立することを内容としてあげている。学級づくりの 指導効果は他の集団との人間関係にる転移するであろ かっこの点てついてても現在では明確な答をすることがで きないし，他律的道徳から自律的道徳への転換を促進す るための指導の重点は何であるか, 道徳的行為の必須要 因である適度の自己制御を発達させる望ましい指導方法 
は何であるか,なども道徳教育上大じな問題でありなが ら，教育の現場は確実な助言を与えられていない。これ らの間題については従来の心理学的研究は多くの示唆を 与えてくれるけれども，現場にお゙いて果して効果をあげ
ることができるかいなかについては確実な証拠を欠いて いるからである。このような点についても教育心理学的 研究が一層進められることを望みたい。

きる。私は, 教育心理学者ば, もつと積極的に教育行政 決定の方面に協力すべきであると思5。現場の数育の技 術面の改善に協力することするちろん必要であるが，政 策の誤りが技術面に困難や混乱をひきおこすばあいがあ ることを考えると，現場の指導に協力する以上に行政面 に積極的に協力すべきであると思5。そのためには，教 育心理学者がるつと学校の管理面や教育行政の実情を理 解することが必要であつて, 调査や研究の方法もこの理 解の上に立つて工夫されねばならぬ。提案者が「下位目 標の設定には教育心理学的研究がもつと重要な役割を演 じなければならないと考光る」と言つていることに対し て，私はこの意味で賛意を表したい。

私達の調査は, $\mathrm{A} ・ \mathrm{~B} ・ \mathrm{C}$ の 3 部から成つているが, $\mathrm{A}$ は道徳意識の傾向を, $\mathrm{B}$ は法律等の権威に対する考え 方や道徳的態度を, Cは高校生と両親との道徳意識のず れを調査したものである。

私達は調查に先立つて, 全国の主な大学, 教育研究所 にお願いして，それまでに行われた道徳教育に関倸を持 つような調查研究の料を送つていただきそれらを検 討し，それらのよいところを取り私達の工夫る加えて調 查票 $\mathrm{A}$ を作つた。これは, 善悪おのおの25面目, 全体で 50項目の個人・社会または集団の行為のランダムな配列 から成り，それらを，＋5からー5までの11殷階の評価 尺度によつて評価させることにしたものである。その祭 自己の評価とは別に，自己の友達の大多数の者の考方方 を推定して,それにるとつくく評価を行なわせた。各項目 についてのこれら 2 種の評価のくい違いの程度は, 私達 に興味のある問題を提供している。ともかく私達は, 調 查Aによつて, 大阪府下の高校生の道徳意識について色 色のことを知ることができた。

この仲間の考方方について閶くという与法は，提案者 もこれに触れているが,この種の調查においては大切な ことであるという確信を持つことができた。

調查 $\mathrm{B}$ は，3つの間題から成つている。例完ば，その 中の 1 つは, 「道路交通取楴法」と「食糧管理法」とい らような法律について, それらが守られないばあいが多 いことを高校生がぞのように考宇ているかを調べたるの である。考元られるいくつかの考光方の中から，自分の 考えと一致するるのを選ばせ，次にそれを選んだ理由と して考えられるいくつかの考光方の中から自分の理由と 
一致するすのを選ばせ，さらにそのような理由でそのよ らな哮え方をするようになつたのは，両親に教えられた からか，学校で教えられたからか，5まれつきか，その 他のるのの影響によるのか，考えらるいくつかの因由の 中からこれそ思うものを選ばせた。る51つの間題は ぞのような数師を尊散するか，その理由は，そしてどら してそう考えるようになつたかを調へ，他の1つは，公 采の面前である道徳的行為についての決意をせまられて いる場面で，どのような態度を選ぶか，そして前と同じ よラになぜどのようにしてを調べたわけである。

この調查 Bにおいても，私達は，仲間の考え方をどう 思了かを記入させることにした。そのばあい自分の考え として示された傾向と，仲間の考えとして示された傾向 との間に興味ある羑異が見出された。

この調查Bの方法は, 私達の 1 つの武みであつたが, このような方法にさらに検郡を加え工夫をこらすならば 道徳教育の政策決定の上にも，道徳教育の実際の指導上 にも参考となるような, 各種の調査を行ないうるるので はないかと考えた次第である。
調査Cは, 調査Aの結果を整理して, 高校生に評価さ せた50項目の行為を, 高校生の評価順に配列し，それを 亮校生の両親だ: :見せて，両者の考え方の一致度を見 よろとしたものである。この調査は，方法上さらに検討 を要する点が残されているが，その結果は高校生とその 親達の考え方のずれについて，かなり興咮深い間題を示 唆している。

前にのべたように，私たちの調査は，指導行政の立場 からの道徳数育の政策決定, 提案者のことばを借りて言 えば，下位目標の設定に役立つ资料を得ることを目的と したもので，したがつて取られた研究の方法すその枠内 で考えられたものに過ぎない。また調查の対象は高校生 であつて，その意味でも籍囲の限定がある。しかるこの 方面の研究法自体に深い考慮をはらつたるのでるない。 したがつて最初に申したよろに，私がここに申述へたこ とによつて，私に課せられた任務を十分に果したことに はならないのであるが，以上によつて報告に代えること にしたい。

\section{報告その2 牛島義友}

のぞましい人間形成がどのようにおこなかれていくか を考えるとき，家庭や学校あるいは社会のいずれが最も 重要な役割を演ずるのかは，人によりまた国により意見 のわかれるところである。この点については，さきごろ わが国および外国の心理学者，教育学者に対して質問炠 を発して調査をしたが，現在まだ未整理であるので，こ こには先般の欧米視察のさいの印象，およびわたくしの 考えているところに従こていくつかの点についてのへた い。

第1亿, ヨーロッパ各国においては，道徳性指導に関 して学校のしめる地位は低く，家庭や社会とくに教会の 意義が大きくとりあげられているといらことがいえる。 したがつて子どもがよくないのは家庭が悪いからだとい 5ように考えるのであり，学校での徳育は一般に毎週の 宗数的儀式や宗教講話による訓育といら形でおこなわれ ている。このことは，他の学校教育計画がすべて学校長 の権限によつて決定されることを嘅めるばあいでも，宗 教教育だけは法律によつて規定されているというような 例にるみられるところである。

それに対して世界観の指導といろことは第 1次世界大 戦後おこなわれてきたのに, 第 2 次大戦後はあまり流行 していないようである。
こんにち日本では「道徳」の時間を特設して道徳教青 をおこなおうとしているのだが，はたしてどの程度の圽 果をあげるであろろか。特設時間をおくにせよ，おかな いにせよ，心理学的には学校全体の雾团気が重要なので あり，そのような全体的な背尌のなかで指導をおこなう ことが必要であると考えられる。

先般の欧米視察旅行のさいの絓験から，学校全体のあ りかたが子どもの人格形成に影稫していると思われると ころをのへてみよう。

学校の教育条件において対照的なのはイギリスとフタ ンスである。

イギリスの学校の数育条件はきわめてよいものであり て, 一般的に小規模の学校が多く, 全校生徒数は 500 人 以下であり，各学級はいずれす25人程度でそれ以上にな ることをきらつている。広い校庭はこの子どもたちに+ 分の運動をあたえることができる。

イギリスの学校の教育目標は，good character の形 成にある。したがつて知育偏重といらことがなく体青 るまたきわめて重要視されるのである。さきの広い校庭 る実にそのあらわれであり，学校スポーツのさかんなこ とも注目に価する。

good character がどこまでも重要視されていること のひとつの証败として, prefect (級長)の例をあげるこ とがでさる。prefect は学校長によつて任命されて学級 のリーダーとなるのであるが，その選択の規準は成續侵 
等ということでなく good character なのである。かれ

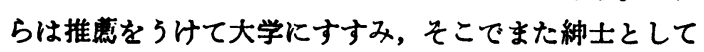
の教青をろけて，やがてイギリスの各界，さらにイギリ ス国家のリーダーとしての生活が期待されているのであ る。たしかにイギリスの数育は選民主義的である（elite system)かるしれない。しかしそれらのリーダーとなる 人たちは奉仕的な人間という規準によつて選ばれてくる のである。

イギリスの学校の教育条件に比べるとフランスのそれ はまつたく悪い。第一，学校の規模が大き，小学校か ら大学まで一カ所にあつて総数 2000 人をこえるようなる のもある。したがつて, “すしゔめ学級”が現出し, 教 師と子ぞもとの結びつきは弱いものになつてしまつてい る。

そればかりではない。教師は授業時間だけ働いて燸つ てしまうのが多いので人格的な硧治がそしいのも当然で あるし，数師間の連絡す不十分である。このような態勢 のるとでおこなわれる数育は，きわめて主知主義的なる のであつて，幼稚園で4才児にまで計算を教えていると

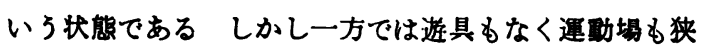
、幼稚園や小学校子多く，体青に対する無関心がはつき り見られるだけでない, 知的内容の指導てあたつては武 験や体野による強制と，賞畔をともならはげしい個人競 争とが重要視されているのである。フランス人の知性は このようにして責われるのであるが，そこには協同作菜 に対する配虑をらかがうことができない。

いまひとつ, フランスの寄宿舎においては私生活は認 められない。個人の戸棚のォギは学校が保管しており, 自由に検閱できるのである。このようななかからフラン スの個人主義がどのよ5にしてらまれてくるのであろう か。わたくしはフランスに批いては抵抗によつて自我か 形成されていく上3に思了。その点イギリスでは，抵抗 など必要がなく，のびのびと個性を発現していけるので はないだろうか。以上, 学校の教育条件が道徳数育とふ かい関連をもつことをのへた。

次に道徳教育の内容についてであるが, 一体価値の体
系というすのは，社会・時代がこれを决定するのであつ て，心理学がこれを决定することはできない。そこで心 理学の間題としては, 道德的性格の形成過程が重要なの ではあるまいか。つまり徳目や道徳の原理よりる道德的 態度をこそ研究すべきであろる。

それでは心理学的にみて道徳的といわれるのはどろい ろことか。われわれがただ要求を満足させていくことは 道徳的行為とはいえない。2つ以上の途があるときそ

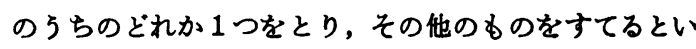
了決断をするとき，その行為は道徳的といわれる。

このばあい，何を退び何をすてるかはそれぞれの時代 によつて異なるのであるが，各時代の代表的な人間は conflict を経験し，そこである決断をなしたという点で やはりその時代において道徳的にすぐれた人だというべ きであり，道徳性はそのような行為をなしうることとい 万点で普週性をるつているといえよう。

決断をすることができるような強い性格の教育がここ に必要となるわけであるが, しつけはその一部をなする のというべきであろ3。いまわれわれは，態度変容の過 程および変容させることの研宪が大切であると考えるの であるが，そのさい，本畝的な態度变容まで考えていか なければならないであろう。最す本賈的な態度变容とは “海い改め (conversion)》あるいは人間改造のことを さすのであるが,これをいま数青のなかでの間題として とりあげていがなければならない。

その意味では，時期的に人間が最初のうそをいる（す なわちはじめて罪を犯す）ら〜 オオのころの指算が最る 重要で,このときの指導が有㚳であるならば人間形成に

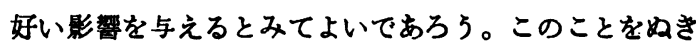
にして道徳教育を考えることはできないのではあるまい か。

なお最後につけ加えるならば,人間改造の間題に関し ては中共やり連にも注目すべきであろらと思らし，また 近来さかんになりつつある集団決定についてるなお模討 の余地があろうと思われる。

（交贵 編集部）

\section{報 告その3 長島貞夫}

沢田氏は, 数育心理学の専攻の徒として, ともに强く 反省して，その解決に全力を注がなくてはならないさま ざまな重要な間題を提出されている。

私はその中から，“指導法の研究の問題”と“判断と 実践のギ+ップ”の 2 つの問題をとり上げて，日拪考元
ていることを述へ，批判をあおぎたいと思う。

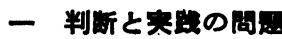

道徳教有の究極的なねらいは，道德的行動であり英践 であることは言うまでるない。ところで，行轩にまでか り立てるもの, 決定傾向, あるいは行功への洹備の状態 として，性格特性と態度を挙げることができる。どのよ らに行動するかは，どのように性格と態度か形成されて 
いるかということにかかつている。

性格は一定の対象に結びつかない一般的な行動の様式 であるがその形成は幼時から展開される人間関係に深く 根ざしている。学校における道徳教育は, 性格の治療, 及び新たな形成を無視することはできないであろう。こ の点で今回の実施要綱が，児童・生徒の現実から出発す るという生活指導の原理に立脚していることは妥当であ ると思われる。よき性格の形成なくしては望ましい行動 が期待されないからである。

態度は性格特性とは異つて，ある特定の対象に結びつ いた野因的態度である。たとえばアメリカが好きで，ソ 連は嫌いだというように。第 2 に態度は判断とか理解と いう知的要因をそのうちに含んでいる。対象について判 断がなされなくては，好きにも嫌いにもならないし，ど う行動したらよいか子わからない。このように態度はあ る対象に関連した動因的状態であり，知的要因をそのう ちに含んでいるという事態の理解が必要である。これを 図式で示せば次のようになるであろう。

\section{態度 $=$ 知識 $\times$ 動機つけ}

したがつて，態度はこれらの 2 要因によつて分類する ことができよう。たとえば動機づけの要因によつて分類 すれば強い，弱い態度がある。動機づけの要因が零にな れば，むはや態度ではなく知識であるにすぎない。

知的構造の明確さによつて態度を分類すれば次のよう であるだろう。妄想的態度, 迷信的態度, 偏見, 先入的 態度, ステレオタイプ, 常識的態度, 科学的態度。

右に述へたよ5に態度はその5ちに知的要因と動因的 要因を含んでいるものであり，したがつて態度の教育は 知識を無視するものではない。正しい態度とは, 正しい 客観的知識に強い動機づけが加えられたものである。知 識は態度の教育の敵ではない。ところで問題は,では知 識を単なる知識に止まらせないで，動機つけをそこに生 じさせる方法はいかなるものかということである。これ は一言で言えば，知識を学習させるプロセスと状況に依 存していると言えるであろう。態度の教育や変容におい て, 状況を重視しなくてはならないという原理は心理学 にお汁る実験的研究から示唆されているものである。

ところで態度測定の問題であるか，従来多くはペーパ ーテストが用いられてきた。これは，意見や判断の調查 であつて, 真の態度測定ではないと批判され，上くに現 場では悪評高きものである。この悪評の根拋にはさきに 指摘してきた態度に知的要因が含まれているということ を無視したところから出ているのではあるまいか。むし ろ態度の知的側面を測るるのとして重視されてないので はなかろらか。サーストン法, リッカート法, ガットマ
ン法の展開によつて，意見や判断の，強度，一貫性など がみられるように工夫されてきており，行動の予見にあ る程度役立つていることが証明されている。娌機づけの 面では，意識の深層にふれているだけにペーパーテスト はどうしても限界があり，したがつて，組織的行動観察 や評定などに侬拠せざるをえない。こうした主観的で はあるがコントロールした方法は工夫されているが，現 場が，むしろ，これを利用する努力を意つていることが 指摘されてもよいのではなかろうか。

\section{二 指望法の研究の問題}

「望ましい指導法は何であるか, なども道徳教育上大き な問題でありながら，教育の現場は確実な助言を与えら れていない」ことを沢田氏は指摘しておられる。このよ うな事態に対しては, 率直に言つて現場の数師側の責任 と, 教育心理学者の責任を指摘しなくてはならないよう に思うのである。

すくなくとも1930年以前の教育心理学的原理は, 孤立 した実験室内でなされた心理学的業績から, 示唆を受け ていた。このような段階では, 学校場面と原理が見出さ れた実験的状況との間に距離がありすぎるために，指導 の原理としてはほとんど役立たないというのが実状であ うた。

しかし，現実の状況の重要な要因を実験室内になるへ く現実の姿のままで持ちこんで，コントロールした方法 で研究をすすめるとい5やり方をレウインが創始して以 来,グループ・ダイナミックスが見出した原理は，現場 における実践に対して, 交字どおり貴重な示唆を提供し ているものと言える。1937年以降展開されているアンダ ーソン (Anderson, H.H.) らの, 数師対児童の人間関 係についての一連の研究も, 現場への貴重な示唆を含ん でいる。るちろん戦後の日本の教育心理学者による業績 も貴重な示唆を提供している。しかし示唆が現実になり ろるか否かは教師側の態度にかかつている。この点で, 現場側には必ずしも，この態度が発展しているとは思元 ないる・のがある。

また教育心理学者側の責任も指摘されなくてはならな いであろう。

臨床的方法やせいぜいグループ・ダイナミックス的方 法で研究することに満足せずに，実践的原理をうち立て るために,アクション・リサーチの方向に前進すへきで はなかろらか。

特定の学校及び学級条件の中で, 学校及び学級が直面 している問題解決のための研究作業をすすめるようなや り方でなくては，沢田氏の言われる，実践的原理は見出 
されないであろう。

アクション・リサーチの研究仮説は現場の現実的間題 から得られるとともに,また教育心理学的な仮説 (たと えば役割理論や態度形成についての実験的研究など）か ら得られるが，現場と心理学者との協力がなされれば， こうした研究の展開は可能であるし, 少数ではあるが行 なわれてるいる。*
*1例ではあるが,ニネスコの英匬学校として指定 された東京教育大学附属学校, 広島大学附属学校, 和 光学園, 川崎市田島中学校が1953年以来行っている教 育実践を举げることができる。(「国際理解の教育」日 本ユネスコ国内委員会刊)ここでは「人梅意識を高め る指導法」「学級つくりと一般的な人椎意識の問题」 「偏見除去の方法」など具体的な問題が統制された方 法で研究されている。

\section{討 論 その概 要}

出席首 (五十音順)

天野利武牛島義友城戸幡太郎(司会)

沢田慶輔長島貞夫野佐三

波多野完治松本金寿依田新

\section{1 道德教育の目電・内容について}

道徳教育における教育心理学的問題といらばあい，ま ずとりあげられたのは，目噤・内容に関する問題であつ た。

この問題については, 別記報告にみられるとおり, 一 方には，目標そのものは時代や社会によつて異なるのが 当然であり，いわば心理学の領域をこえたところできま つてしまうのである。心理学がとりあげるのは道徳意識 の㗢き (道徳的判断) であつて, 内容がいかに相対的で あり変遷していこうとも，ある一貫性をもつものとして 换討してよいのではないか，という意見があり，他方に は, 教育心理学はもつと教育政策・教育行政の面に関与 すべきであり，道徳教育の目標設定にも参加するのが望 ましい,とする見解があつた。この見解の相違をめぐつ て活発な討論がかわれた。

すなわち，第1の意見としてA氏は，どのような行動 を選ぶべきかといらことを指導することがはたして道徳 教育といえるかどらか間である。それはたしかに道徳 的価值に関係はしているが，むしろ知部教育であつて道 徳教育ではない。たとえば，ある行動のしかたの価值に ついて論争がおこつているばあい，これを論争として論 理的に教えていくことはできる。しかし，それで道徳教 育がおこなわれたわけではない。今日の社会で承認され ているような行動のしかたを教えるといらようなことは 道德教育としては末梢的なことであり，道徳教育に対す るより根本的な要誚は，すぐ決断して央践にうつすこと のできる強い性格の形成にある。したがつてなんらかの 政治性のふくまれた道徳教育とい5ものはありえないし またそのような教育に対しては父兄のなかにも反対があ るであろう，とする。
しかし、これに対してB氏は，たしかに高い道徳性を もつということはいろいろな conflict の場面を経てくる ことによつて可能になる。いわゆる知識をむたない人た ちのなかにも深みのある人はいくらもいる。しかし，現 在学校教育の場面でおこないうる道徳教育は, そのよう な深みのある人間を形成するというような理想的で高遇 なものでなくて，いまの社会で承認されらるょう行為の しかたを教え，悪いことをしない人をつくろう，という ものであつて，これが最近間題になつているのであろ ろ。もしころいうことを道徳教育といわず，高䄲な人間 形成のしごとだけを道徳教育となづけるべきならば，学 校教育ではできないことになつてしまうのではないか， との意見を出した。

かりに，学校教育のなかで子どもたちに，梅い改めを とおして道徳的決断の力を与えていくことができるとし てる，日本の現状ではこれを強力にすすめていくことは 不可能に近いといわざるをえない。そこで現在実施ので きる方策を考充なければならないわけで，交部省が実施 要綱の作成を急いだのも，そのためのひとつの対応策で あつたとも考元られた。

それでははたして要綱にとりあげられた内容はどんな 意味をもつているのであるらか。討論はこの点について 展開された。

C氏は，この要綱の価値は，子どもの道徳教育を学校 や家庭・社会がどのように分担してたこならべきなのか が検討され，その5えで学校教育における「道徳」の特 設時間がどの程度の役割をにない，どれ和どの効果をあ げうるものなのかか明確にされてからでなければ正しく 評価できないであろらが，そこでとりあげられる内容は 慎重に選ばれなければならないはずである。というのは 
内容のなかには,どんな社会にも，どんな階㬝にも共通 して必要なるのもあるとともに，一方にはある社会，あ る階層においてとくに強調されなければならないすのも あるからである。したがつて現在の日本の社会に即して 考えていってよいと思われる。共通に要求されるへき内 容（大成）と，各階層に特有の内容とが構成しているこ の価値の体系（価値の hierarchy）がどうなつているの かを問題にしなければならない,とのべた。

それに対してD氏は，たしかに階層差はすへてて教育 内容について存在することは事実であるけれどす，それ らを十分に考虑することは, 要細においては困難である う。その意味で，不十分ではあるがまず重要と考えられ る内容を網羅的にとりこも5と試みたのが今回の要網で あるとみれば，それで一応道徳教育の方向をしめしたも のとしてよいのではあるまいか。るちろん今回の内容に われわれは満是しているのではなく，とくに内容か羅列 的にならべられているにすぎないという点ではこれから なお研究すべき余地がお批いにあると考えられる。たと えば，妥とか正義とかいうような基本的中心的な目潔と 周辺的なるのとを判別していく作業がわれわれをまつて いるのである，との意見をのべた。

さらにE氏は，文部省の要絧か沅在の道徳教育の課題 となつていた指導内容の整理と明確化を試みたことは意 義のある努力であつたとして基本的には賛意を表わしな がらも，内容があまりに包括的羅列的にすぎることを指 摘し，交部省の要絧はもつとも基本的な点だをおさえ ておき，その他の内容一下位目標については各地方の 教育委真会の検討にまかせそそれぞれの地城社会が望ま しいとする内容をそれにらくませるようにすべきで，現 在のありかたとしてはそれよりはかにはしかたがないの ではないか，との意見を出した。

以上のような討論に対してF氏からまつたく遠了観点 からの見解が発表された。それによれば，道徳教育は具 体的な生活場面でぞ 行為するかを間題にするが，その 行為を評価する規準がなければならない。そこで一定の 立場が入つてくる,といわれる。

すなわち, 道徳的行為を conflict の場面で正しく決断 することだと考え，侮い改めをうながすことによつてそ の決断の力を与えることを道徳教育としたばあいに問題 になるのは，海い改めは形式的なものであつて，価值判 断の対立 conflict に直面してどちらを選ふかかは時代によ つて異なる。したがつて封建時代にはきわめて高く評価 された钱牲的行為も今日は別の角度から価值判断される わけである。同じように，ある調査によつてかりに道徳 意識の実態があきらかにされたとしても，この事実を望
ましいとみるか, 望ましくないとみるかは，人により立 場によつて䔬なる。

価値判断の内容のくいちがいは生活栐式のちがいから らまれるものであると考えられるのであり，したがつて 判断の形式だけで道徳教育の内容を考えることは十分て はない。(つまり Formaletik ではなく，Wertetik の立 場が必要である。しかし，だからといつて多数の下位目 棒を設定することでことたれりというのではない。なぜ なら下位目標（それは徳目となる）をならへるとき，具 体的な生活場面からの抽象化がおこなわれるためにた がいに矛盾するような内容が並ぶことすあり，価値観の 対立がそこでも問題になり，指導者によつてまつたく相 反する結論が導き出されるばあいるある。たとえば文化 人類学でも道德的内容を間題にしているが，そこではあ る cultural pattern がしめされるだけで，教育的な観点 からなにが重要であるかをみきわめることはできない。 また社会構造の視点からこれを分析するというす必要な ことであろう。

道徳教青は, 子どもが具体的な生活埸面に直面し，そ こから自分らで新しい生活㥞式をらみ出すことのなかで おこなわれるのである。つまり価値を新しく飤造してい くところに道徳的判断の中核があるのだとみていきたい のである。徳目のるつ言語の魔征にかかることなく, む しろこれを批判的にうけとめることがより道徳的なので ある。このことによつて個人と集団との道徳意識のズレ をどうするかという課題にも応えていくことができると 考えられる。

以上の意見に関連して，G 氏が次のような見解を発表 した。

社会の移行期には, 道徳的 personality の形成は必要 であり，そのために性格数育が重要視されなければなら ないがそれだけでは十分ではない。

価値体系は相対的なるので心理学はただそれに奉仕す るものだとい5意見が出されたけれども, 生理学あるい は心理学の立場から人間性に反しているか否かを判断す ることもできるわけで，心理学は人間性の正しいのび方 をしめすことによつて価値体系の構成に貢献することも できるのである。

人間性をのばすという锶点にたつばあい，一般に道徳 と対立して悪いものというように考えられている本能と よばれるようなものを道徳的行為の根源と考えるべきで あり。欲求満足ということを conflict の克服とともにあ わせて考虑することが必要なのである。それは欲求の满 足がないと精神徱生のうえで望ましくない結果を生じる ことになり，結局人間性が歪められるからである。倫理 
学においてはこの精神箱生の筧点が久けけいるのではあ るまいか。

このような観点からすれば conflict がおこつつばあい id を価值の創造に参加させることによつて， complex をおこさないよ5に指導するのが道徳教育であるとされ る。

\section{2 逆德数有の方法と数皈の役讨について}

道徳教育の目標・内容の問題とならんで重要なのは, その指導法である。すなわち，指導計画を実践していく ばあいの動機つけの問題および判断と実践との関係をめ ぐる問題である。

現在, 少年.非行の状態をみると, かならずしも思考力 のないものが犯罪をおかすというのではなく，学校です 家庭でもよい子と考えられているようなもののなかに犯 罪をおかするののあることが報告されており，ある調査 の結果では，登みをすることを冓いことと考えない子ど ものあることがあきらかにされている。こういう事実を 前にして，道徳教育の実施の方法はきわめて重大だとい わなければならないが，今日までのような主知主龙的な 通り一辺の方法では十分でないことは当然である。

H氏は「道徳」の実施要綱に関連して，この要絧があ まりに網羅的であるために，すへての項目を全部教えな ければいけないと教師が考えるようになりがちであり， そのような譔解が，奻果のない無益な努力をひきおこす ことを警戒しなければならないし，われわれもそのよ5 な事態のおこらないように対策を考えなければならない と指摘した。

また，たとえば「自分の生命を大事にする」といらよ 5な内容は 1 回だけでなく，各発達段階に応じてそれぞ れの生活事実に即して具体的な内容としてくりかえし指 導していくことが必要であつて, 全項目を学年学期にわ りあてて教えるというような教科学習の教材との混同を 注意すべきである，とのべた。

またG氏は，視聴覚教育において視聴筧的提示と実践 とのあいだには千歩の距離がある，といわれることから 道徳教育がただ単に言語的あるいは視聴覚的な内容提示 だけでは効果がないこと, 行為の学習のなかにも比較的 容易に定着しやすいものと，そ5でないるのとがあるが いずれにしても motivation が重要であると説いた。

ここてで問題になつたのは conditioning と motivation との成係であつたが, この点については Pavlov らの古 典的条件つけにおいて対置されていた conditioning と motivation とは, Iwanowsky Smolensky らの新しい条 件づけでは motivation の基碟を無条件反射におき, 両
者を同一方向に湖かせることを考えるようになつた。し たがつてさきの本能の嘢きを道徳的行為の根源と考えよ らとするとき id に対して，交化を motivation として 与え, 両者を協同作用させることが必要なのである。

ところで一般に条件づけのとき, 実検者の存在がひと つの前提となつているのと同様に, 数育の場面において 数師自身が動挠づけの重要な役割をはたしていることを 考えるならば，数師をふくんだ場面全体が子どすにある 種の行為を5ながす力をるつているのだとみるべきで， action research はそれ自体ひとつの治療であり, 研究 そのものが action research でなくてはならないであろ 3。そこで数師の人格が開題になつてくる。とくに小学 校のばあいには，学級担任の数師個人の影籍がかなり入 ることは否定できないであろう。

しかし道徳教育, 人間形成のばあい, 教師としていか に人格がくてもそれでは十分な条件ではない，とA氏 はのへる。つまり，教師が道徳的な内容を教えよ 5 とす るのではなくて，教師みずからが子どすとともにあゆみ 苦悩することが，子どすたちによい影䈏を与えるのであ る。この人間として苦悩する奖が子どすのに忽的をひ きおこすのである。したがつて教師であるという意識を すてて子どすたちに対するときに、はじめて道徳数育の 奻果を期待できるのである。

その点で，宗数数育のばあいには，自分が教育しよう というのでなく，至らない人間ではあるが共なに神の御 手にひたすらすがつていくといろ心でつらぬかれている から，そこにおのずから人格的な成長が期待できるので あるが，数育のばあいには教師がとしても自分で指労 しなければならないと考え，しか子教えるときの扰りど ころる確かでない。そこにいろいろな困難がうまれてく るのであろ5。こう考えると，道德救育というすのす， 究極的には宗数教育までこなければならないと思う，と いうのである。

それに対してF氏は，次のような意見をのへた。

子どもとともにあゆむというとき，教師として子とも たちの集団生活になにか操作を加えて变革を与えていく 事は当然の事である。しかし，その過程において子ども とともに生活のなかにおこる問題を考えていくことによ つて道徳を創り出していくことができるのではないか。

ただし，道德数育においてすつとも間題となる不適応 児は,どうしても現代の杜会にまず適応させるというこ とが必要で,これは, therapy の問題となる。

したがつて道徳教育には，子どすたちに価值を創造さ せていくといら指導と，therapy との 2 つの側面を考え ていかなければならないであろう，とする。 
さて，以上の教師の討論を通じて基本的に重要だとさ れたのは教師の指導能力差のことである。教師の人格や 能力差の存在は否定できないことであり, よい数師につ いた子どもは道德性の発達に有利で, そうでない子ども は不利だとい5心配がある。われわれはどの教師につい ても同じような成果を期待したいし，それが可能になる ような配虑がなされなけばならないという意見が出され たのである。

交部省の要綱が，その点では意義をもつているとする 意見も出されたが，また教師集団の組織化の必要子説か れた。

すなわち，1 人の数師が学級を指導するとだけ考兄， 教師対生徒集団の局面でだけみていくならばたしかにそ れぞれの数師 1 人 1 人の人格によつて条件がきめられて くる。そこで, 学校全体が教育活動をしているのだと考 え，教師がたがいに協力していくならば教師 1 人 1 人の 差はそれほどの重要さをもたなくなるであろう。そのた めに, 子どすの行動観察なども1人だけでやるというの でなく, 何人かの教師の協力によつておこなつていくへ きであるというのである。

るらひとつ道徳教育の実践に関して重要な点は社会的 な事情を考虑することである。討論は十分発展しなかつ たが, 長島氏の 態度=知識 $\times$ 動㙨つけ に対して, 知 識や動機つけけがあつても社会的事情のために実行できな いばあいがありここれが今日の大きな間題である，との 指摘があつたし, 道徳的判断に関する世代の差をどのよ ラにすべきかを考えなければならない，という意見す出 されたことをあげておかななればならない。

\section{3 道德教育と教育条件の問题について}

道徳教有に社会的な事情がふかく関係しているここは 指摘されたとおりであるが，学校ないしは教師をめぐる 各種の条件は，さらに重大な影響力を教育活動に与えて いるので, この点についての発言も多くあつた。

その条件の第 1 は過大学級であり, 第 2 は教師の勤務 評定である。

過大学級の問題については, 西ドイッではたとえ 2 部 授業になつても，指導の責任を保証するために 1 学級 40 人以上になることを拒否しているという例がかれ，道 徳教育の実施を急ぐょりも現在の学称生徒数を半減する ための方策をとつたはうがはるかに効果的であるとの見 解が出され，教育心理学が教育行政面に参加するという 点からタ.この種の教育条件についての研究をすすめて 結論を出し，実施するよう勧告すべきだとの意見がほと んどすべての出席者の同感をえた。なお゙, その件につい
ては教育課程審議会です十分検討されており，その実現 を前提として，道徳教育がさきに発足したという事情も あきらかにされた。

第 2 の勤務評定の間題に関しては，さきの数師集団の 組織化と関連して，F代道徳教育の実践にあたつては 教師の組樴化がきわめて重要であるのに，今回実施され つつある勤務評定は個人としての教師を評価しているこ とによつて，教師の結束を乱す結果になつている，と指 摘した。

これらの教育条件の改善が道徳教育の推進と不可分の 関保にあることが討論のなかで原則的にみとめられたが 十分娭討する時間的余裕がなかつた。

\section{4 研究法について}

教育心理学が道徳教育の研究に面献する第 1 のすじみ ちは，問題点をとり出すことにあり，第2のすじみちは 測定のための用具を作成することである，と長島氏は提 案に対する報告に関連してのべているが，測定の用具と しては。各種の態度尺度その他組織的観察などがとりあ ゲられよう。討論においてはこれらの測定法ないしは研 究法についての意見の発表がわずかながらみられた。

長島氏はユネスコの国際理解の教育の協力員として人 権に関する態度尺度およびその他の側面からの社会的態 度尺度を作成し，実験協力校での action research に用 いたのであるが,これら評定の量化の手続きが間題にな つた。たとえば，5段階評定のばあいの数値のるつ意味 の吟味が十分されていないと, 結局教育心理学そのもの の意義までがうたがわれる結果になつてしまう。そこで 量化の手続きが十分におこないえないときにはむしろ 質的評価を考えて類型法を用いたほうがよいばあいがあ る。傾向をさぐろらとするのならば，量化法のほうがよ いこともあろうが，十分慎重でなければならない。

第 2 に問題になるのは, 道徳教育のばあいには, 一定 の目標（立場）をるたざるをえないわけで，量化する方 法ではますます結論をひき出すことがむずかしくなるで あろろ。乙たがつて，常に結果を検討するばあいの観点 を明確にしていかなければならない

また測定の結果が平均とかなりかけはなれているょう な個人あるいはその集団についてはそれがどのような理 由によるものかがらかがえるようにしておかなければな らない。

以上の内容は，かならずしも討論の展開にそつたもの でなく，内容によつて適宜 4 䬣にわけ発言を整理したも のである。（文責 編集部） 


\section{討論を同いて 宮坂哲 交}

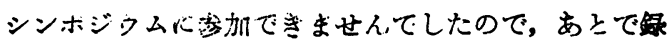
音をきかせていただいた感想を一二のへて資をふさぐこ とにします。

討諭のなかで，道徳教睯と行徳目などを言葉として教 える知識教育のことではなく，コンフリクトを含んた現 実の生活場面での行動の選択の指遒を意味すべきすので あるとの意見と，そんなことは現埸の教師にはできない から，道徳教茅の「下位目標」をなるべくこまかく示し てやることが必要であり, 現場はそれを要求していると の意見が対立的に出されています。前者の意見はさら に，それはちようど宗教教育におけるコンシァージョン に当るるので，発達心理学的にそうい5危機はすくなく とも 1 回はある（たとえばウりをはじめてつく6才ご ろ）そういう機会をとらえて，「くいあらため」の経験 をもたせることか真の道徳教育たという説明もあり，宗 教教育を原型として考えている意見のように思われま す。そしてそれが，そんなことはふつうの光生にはでき ないといら反論をまねく一因になつているかと思われま すが，私はこのような立場を公教育の場において一般化 することが必要でもあり, 可能ですあると考えます。と いうよりも，このような道徳教育は, もつと一般的な形 で，いまの日本の学校でひろく行われていることであつ て，それ、を理論化し方法化することこそが些面の私たち の課題だと考えるのです。

たとえばこんな例があります。ある小学校の 2 年のク ラスで放課後の搮除のとき，2人の子どもがいなくなつ てしまつた。あとできくと便所へ行きたくなつて教室を 出たら 1 年のとき受持だつた $S$ 先生にかい,ちよつと手 伝のてくれといわれて手伝つていたという。次の日先生 はこの間題をみんなになげかけて話合”たところ, 手伝 つたんたからよいという意見や掃除のとさどこかへ行つ てしまうのはいけないというような意見がいろいろ自由 に出されていくうちに，「S 先生にたのまれたとき，先 生にきいてからくるといえばよかつた」という意見や， 「S 先生に掃除がおわつたらきますといえばよかつた」
といつた意見が出てきてまとまつたという。（川合章繝 「子どすの認識を高める論理」24一25頁）子どすたちの 每日の家庭や学校の生活のなかにいつばいころがつてい るこうした場面でどう対処するかを，子どもたちのなか に入ンて一緒に考え，実践していくところに前者の意見 を让しく生かしていく道があると考えます。自他の要求 の対立矛盾のなかでど5自他を尊重し，自他を生かすか について，観念的にでなく（徳目からでなく）具体的に 判断して行動するという生きかたこそがねらいであつて そろいう努力を子どもたちに期待するだけでなく，教師 もまたそれを自分自身に課していくことが必要になつて くると思います。このような教育実践の過程の心理学的 解明を数育心理学にも期待したいと思うのです。

あとの方で言語魔術にかかつてはならないという警开 も心理学的にやうていかねばならないといわれた F氏の 意見も全く同感です。そういう意味でも，私は子どすに 拈ける bebavior と perception の相互関係の一周の解 明を期待したいと思います。教育学でも実践と認識の閶 係がさまざまな形でとわれていますが，そのばあいです 子どもたちが，現にいとなんでいるるのの見かた感じか た，考えかたの事実を理解し，そこから入つて実践の向 上への道を留くしごとを, 社会や自然についての客観的 な認識をあたえるしごととともに重視しています。

価值体系にたいして心理学がただ奉仕するだけでなく 子どもの人間性の研究という立場から価値体系を積極的 に批判していくべきだとの意見にはだいんん力強いもの を感じました。

.道徳教育については集団の問題もぜひとりあげていた だきたいと思います。討論では，個人としての教師にあ まりに過大なる要求がかけられすぎたようにかんじまし た。文部省の道徳実施要綱も, 道徳の問題を個人の問題 に局限し解消させている上うに思います。子どもたらが 自分たちの足るょの問題に自分たちで気つき，自分たち の力でそれにとりくんで困難を打開していくところに新 しい道徳が育つていくという考えかた，一ロでいえば学 䄲集団の道徳探求の主体性と自由という考えかたが稀薄 で, 教師中心の授業に傾く危険が強くかんじられます。 